\title{
THE CHILD
}

IN SPANISH CINEMA sarah Wright

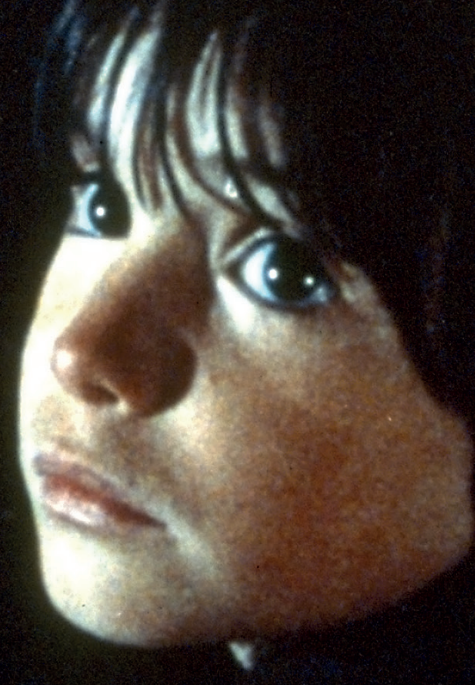




\section{The child in Spanish cinema}

\section{MANCHESTER 1824}

Manchester University Press 
Sarah Wright - 9781526103192 Downloaded from manchesterhive.com at 04/26/2023 06:50:16AM via free access 


\title{
The child in Spanish cinema
}

\author{
Sarah Wright
}

Manchester University Press

Manchester and New York

distributed in the United States exclusively by Palgrave Macmillan 
The right of Sarah Wright to be identified as the author of this work has been asserted by her in accordance with the Copyright, Designs and Patents Act 1988.

Published by Manchester University Press Oxford Road, Manchester M13 9NR, UK and Room 400, 175 Fifth Avenue, New York, NY 10010, USA

www.manchesteruniversitypress.co.uk

Distributed in the United States exclusively by

Palgrave Macmillan, 175 Fifth Avenue, New York, NY 10010, USA

Distributed in Canada exclusively by

UBC Press, University of British Columbia, 2029 West Mall, Vancouver, BC, Canada V6T 1Z2

British Library Cataloguing-in-Publication Data

A catalogue record for this book is available from the British Library

Library of Congress Cataloging-in-Publication Data applied for

ISBN 9780719090523 hardback

First published 2013

The publisher has no responsibility for the persistence or accuracy of URLs for any external or third-party internet websites referred to in this book, and does not guarantee that any content on such websites is, or will remain, accurate or appropriate.

Typeset in 10/12 Sabon by

Servis Filmsetting Ltd, Stockport, Cheshire 